\title{
Deletion polymorphism in the angiotensin I converting enzyme (ACE) gene as a genetic risk factor for sarcoidosis
}

Ken Furuya, Etsuro Yamaguchi, Akihide Itoh, Nobuyuki Hizawa, Noritomo Ohnuma, Junichiro Kojima, Natsuko Kodama, Yoshikazu Kawakami

\begin{abstract}
Background - Genetic control of serum angiotensin I converting enzyme (SACE) levels has been suggested. A study was undertaken to elucidate the role of this polymorphism in sarcoidosis.

Methods - Three hundred and forty one unrelated healthy controls and 103 consecutive patients with sarcoidosis participated in the study. SACE levels and an insertion/deletion (I/D) polymorphism in intron 16 of the ACE gene were studied in each subject and new reference intervals for SACE activity for each genotype were determined. The difference in genotype and allele frequencies between controls and patients was analysed and odds ratios were calculated to estimate the relative risk.

Results - A significant association was seen between ACE gene polymorphism and SACE levels in both patients and controls. The new reference intervals for each genotype discriminated abnormal SACE levels in patients more accurately, especially those with genotype II. In women the frequencies of allele I were 0.68 (allele $D$ 0.32 ) in controls and 0.58 (allele $D$ 0.42) in patients, and the difference between the two female groups was significant (p $<0.05)$. Thus, an excess of genotype ID or DD was observed in female patients (odds ratio 2.18 ; $95 \%$ confidence interval 1.18 to 4.01; $p=0.01$ ).

Conclusions - These findings suggest that ACE gene polymorphism is associated with SACE levels in both patients with sarcoidosis and controls. ACE gene polymorphism should be further evaluated as a candidate marker for an increased risk of sarcoidosis.

(Thorax 1996;51:777-780)
\end{abstract}

Keywords: angiotensin I converting enzyme (ACE), ACE gene polymorphism, sarcoidosis.

Since Lieberman's report in $1975,{ }^{1}$ measurement of serum levels of angiotensin I converting enzyme (SACE) is known to have potential value in confirming the diagnosis and estimating the activity of sarcoidosis. On the other hand, in various series of patients with active sarcoidosis the prevalence of increased SACE levels has ranged from $33 \%$ to $88 \%$. $^{2}$ It is also reported that black subjects tend to have higher SACE levels than whites in sarcoidosis. ${ }^{3}$ These findings suggest that there may be genetic or racial differences in SACE levels in patients with sarcoidosis.

In normal adults SACE levels can differ greatly from subject to subject by more than five times, ${ }^{14}$ but in a given subject SACE levels remain relatively constant. ${ }^{5}$ Population-based reference intervals for SACE levels are therefore recognised as having some limitations to detect abnormality because the interindividual variation is greater than the intra-individual variation. ${ }^{6}$ Cambien et al reported familial resemblance of plasma ACE levels in a large family study. ${ }^{7}$ After cloning of the human endothelial ACE gene, ${ }^{8}$ a genetic control of plasma ACE levels has been suggested by the identification of an I/D polymorphism of the ACE gene. ${ }^{9}$ We have studied the predisposition to sarcoidosis, as well as the genetic regulation of SACE levels, in patients with sarcoidosis and in controls from the point of view of polymorphism of the ACE gene.

\section{Methods}

SUBJECTS

Three hundred and forty one healthy unrelated Japanese subjects (179 men) of mean (SD) age 42.5 (11.5) years, recruited from subjects who presented for a medical check-up, were selected as controls for the study. Patients with sarcoidosis and those with any other diseases who were receiving medication such as ACE inhibitors, or on the basis of physical examination, chest radiographs, electrocardiograms, and routine laboratory tests were excluded.

One hundred and three consecutive patients with sarcoidosis (33 men) of mean (SD) age 39.5 (16.4) who attended our university clinic from June 1974 to December 1993 were also included. All patients except five had chest radiographic evidence of disease including 60 
with stage I, 29 with stage II, and nine with stage III disease. The diagnosis of sarcoidosis was established clinically and pathologically in all patients. They had compatible clinical and radiographic features without evidence of mycobacterial, fungal, or parasitic infection. Seventy five of the 103 patients had biopsy evidence of non-caseating epithelioid cell granuloma. None had a history of exposure to organic or inorganic materials known to cause granulomatous lung diseases. They were followed for at least 12 months to confirm that their clinical course was consistent with sarcoidosis.

All controls and patients were Japanese from central Hokkaido in Japan.

\section{ACE MEASUREMENT}

SACE activity was measured by the colorimetric assay (ACE Color, Fujirebio Inc, Tokyo)..$^{10}$ Serum samples were stored at $-70^{\circ} \mathrm{C}$ until the assay was performed. SACE activity was evaluated in all controls and in 84 patients on the initial visit without corticosteroid therapy, beginning in August 1983 when this assay method was adopted. Nineteen of the 103 patients who presented before August 1983 or who had already been given corticosteroids were excluded.

\section{DETECTION OF ACE GENE POLYMORPHISM}

Genomic DNA from subjects was prepared from peripheral blood leucocytes. A 287 base pair (bp) I/D polymorphism in intron 16 of the ACE gene was examined by polymerase chain reaction (PCR). ${ }^{11}$ Briefly, two primers, sense oligo 5' CTGGAGACCACTCCCATCCTTTCT 3' and anti-sense oligo 5' GATGTGGCCATCACATTCGTCAGAT 3', were synthesised to amplify the polymorphic fragment. Reactions were performed with $10 \mathrm{pmol}$ of each primer in a final volume of 501 containing $100 \mathrm{ng}$ of genomic DNA, $3 \mathrm{mM}$ $\mathrm{MgCl}_{2}, 50 \mathrm{mM} \mathrm{KCl}, 10 \mathrm{mM}$ Tris- $\mathrm{HCl}, \mathrm{pH}$ $8.4,0.1 \mathrm{mg} / \mathrm{ml}$ gelatin, $0.5 \mathrm{mM}$ of each $\mathrm{dNTP}$, 1 unit of Taq polymerase (Perkin Elmer Cetus, Norwalk, USA). The DNA was amplified for 30 cycles as described previously. ${ }^{12}$ The PCR products were subjected to electrophoresis in agarose gels and visualised by ethidium bromide staining. Each allele and genotype was determined.

\section{STATISTICAL ANALYSIS}

SACE activity was expressed as mean (SD) IU $/ 1$ at $37^{\circ} \mathrm{C}$. The following statistical analyses of SACE activity were carried out using log transformed values. The new reference intervals of SACE activity for the whole and for each genotype of the ACE gene were expressed as $95 \%$ ranges of SACE activity in controls. The association of the ACE gene polymorphism with SACE activity was analysed using one-way analysis of variance (ANOVA) followed by Scheffe's F test for multiple comparisons separately in controls and patients. The unpaired Student's $t$ test was also used to compare SACE activity between controls and patients. The difference in allele and genotype frequencies between controls and patients was tested by $\chi^{2}$ analysis. Odds ratios were calculated to estimate the relative risk of sarcoidosis and the analyses were carried out by using logistic regression models adjusted for sex and/or age.

\section{Results}

A $190 \mathrm{bp}$ fragment without the insertion (allele D) and a $490 \mathrm{bp}$ fragment with the insertion (allele I) were demonstrated and three possible genotypes were represented as II, ID, and DD as described previously. ${ }^{12}$ SACE activities in controls and patients are shown in fig 1 . The mean SACE activities (IU/ 1 at $37^{\circ} \mathrm{C}$ ) for genotypes II, ID, and DD were 11.8 (2.9), 15.2 (3.6) and 19.3 (3.9) in controls, and 18.7 (4.7), 27.5 (11.9) and $32.7(9.8)$ in patients with sarcoidosis, respectively (table 1). The association of the ACE I/D polymorphism with SACE activities was significant in both controls $(\mathrm{p}<0.0001)$ and patients $(\mathrm{p}<0.0001$, table 1). There was a significant difference in SACE activities between two arbitrary control groups (II < ID, ID < DD, II < DD, p < 0.0001). SACE activities in patients with genotype ID or DD were significantly higher than in those with genotype II, but there was not a significant difference in SACE activities between patients with genotypes ID and DD. After adjustment of the three genotypes, SACE activities in patients were significantly higher than in controls (table 1). Our new reference intervals (95\% ranges) of SACE activity in controls are also included in table 1 .

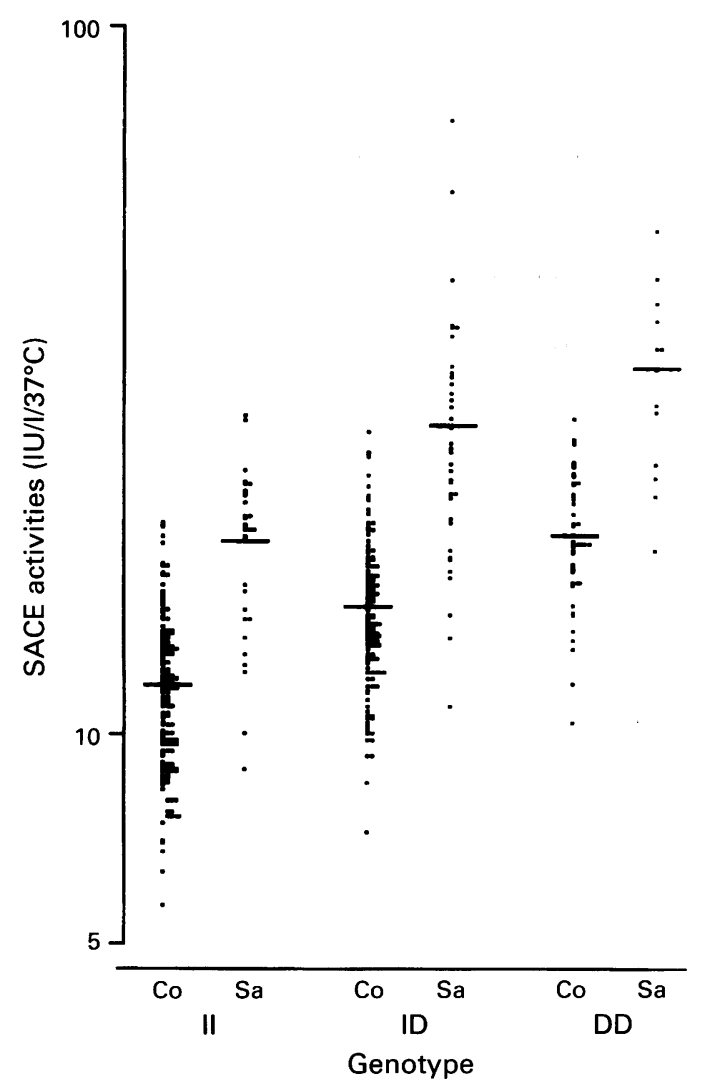

Figure 1 Serum angiotensin converting enzyme (SACE) activity (IU/l at $\left.37^{\circ} \mathrm{C}\right)$ in controls (Co) and patients with sarcoidosis ( $S a$ ) with three different ACE genotypes (II, ID, $D D)$. Horizontal bars indicate mean $S A C E$ activity in each group. The $y$ axis is log transformed. 
Table 1 Association of the ACE I/D polymorphism with mean (SD) SACE activities (IU/l at $37^{\circ} \mathrm{C}$ ) in patients and controls

\begin{tabular}{|c|c|c|c|c|c|}
\hline & \multirow[b]{2}{*}{ Total } & \multicolumn{3}{|l|}{ Genotype } & \multirow{2}{*}{$\begin{array}{l}p \text { value } \\
(A N O V A)\end{array}$} \\
\hline & & $I I$ & $I D$ & $D D$ & \\
\hline Sarcoidosis & $25.1(10.7)(n=84)$ & $18.7(4.7)(n=31)$ & $27.5(11.9)(n=40)$ & $32.7(9.8)(n=13)$ & $<0.0001$ \\
\hline Controls & $14.2(4.2) \quad(n=341)$ & $11.8(2.9)(n=158)$ & $15.2(3.6) \quad(n=138)$ & $19.3(3.9)(n=45)$ & $<0.0001$ \\
\hline $95 \%$ ranges & 7.6 to 24.2 & 6.8 to 18.2 & 9.3 to 23.5 & 11.5 to 26.9 & \\
\hline $\begin{array}{l}\mathrm{p} \text { value } \\
\quad \text { (Student's } t \text { test) }\end{array}$ & $<0.0001$ & $<0.0001$ & $<0.0001$ & $<0.0001$ & \\
\hline
\end{tabular}

Table 2 ACE genotype and allele frequencies in patients and controls

\begin{tabular}{|c|c|c|c|c|c|c|}
\hline & \multicolumn{2}{|l|}{ Women } & \multicolumn{2}{|l|}{ Men } & \multicolumn{2}{|l|}{ Total } \\
\hline & $\begin{array}{l}\text { Sarcoidosis } \\
(n=70)\end{array}$ & $\begin{array}{l}\text { Controls } \\
(n=162)\end{array}$ & $\begin{array}{l}\text { Sarcoidosis } \\
(n=33)\end{array}$ & $\begin{array}{l}\text { Controls } \\
(n=179)\end{array}$ & $\begin{array}{l}\text { Sarcoidosis } \\
(n=103)\end{array}$ & $\begin{array}{l}\text { Controls } \\
(n=341)\end{array}$ \\
\hline \multicolumn{7}{|l|}{ Geneotype distribution } \\
\hline $\mathrm{DD}(\%)$ & $10(14 \%)$ & $20(12 \%)$ & $4(12 \%)$ & $25(14 \%)$ & $14(14 \%)$ & $45(14 \%)$ \\
\hline ID $(\%)$ & $39(56 \%)$ & $64(40 \%)$ & $14(42 \%)$ & $74(41 \%)$ & $53(51 \%)$ & $138(40 \%)$ \\
\hline II $(\%)$ & $21(30 \%)$ & $78(48 \%)$ & $15(45 \%)$ & $80(45 \%)$ & $36(35 \%)$ & $158(46 \%)$ \\
\hline Odds ratio* & \multicolumn{2}{|c|}{2.18} & \multicolumn{2}{|c|}{0.98} & \multicolumn{2}{|c|}{1.57} \\
\hline Confidence interval (95\%) & \multirow{2}{*}{\multicolumn{2}{|c|}{1.18 to 4.01}} & \multirow{2}{*}{\multicolumn{2}{|c|}{$\begin{array}{c}0.45 \text { to } 2.17 \\
\text { NS }\end{array}$}} & \multirow{2}{*}{\multicolumn{2}{|c|}{0.97 to 2.53}} \\
\hline $\mathrm{p}$ value & & & & & & \\
\hline \multicolumn{7}{|l|}{ Allele frequency } \\
\hline $\mathrm{D}$ & 0.42 & 0.32 & 0.34 & 0.35 & 0.39 & 0.33 \\
\hline I & 0.58 & 0.68 & 0.66 & 0.65 & 0.61 & 0.67 \\
\hline $\mathrm{p}$ value & \multicolumn{2}{|c|}{$<0.05$} & \multicolumn{2}{|c|}{ NS } & \multicolumn{2}{|c|}{ NS } \\
\hline
\end{tabular}

* Odds ratios were calculated to estimate the relative risk of sarcoidosis in subjects with either genotype ID or DD compared with genotype II by using logistic regression models adjusted for age and/or sex. NS = not significant.

Genotype and allele frequencies in controls and patients with sarcoidosis are shown in table 2. The distribution of genotypes II, ID, and DD in all controls was $46 \%, 40 \%$, and $14 \%$, respectively; allele frequencies were 0.33 for allele $\mathrm{D}$ and 0.67 for allele $\mathrm{I}$. These results were in agreement with Hardy-Weinberg's equilibrium. Genotype and allele frequencies were not significantly different between men and women in the control group but, in women, the distribution of ACE genotypes was significantly different between patients and controls $(p<0.05)$; thus the frequencies of allele I were 0.68 (allele $\mathrm{D}, 0.32$ ) in controls and 0.58 (allele $\mathrm{D}, 0.42$ ) in patients, and the difference of the allele frequencies between the two female groups was significant $(p<0.05)$. An excess of genotype ID or DD was observed only in female patients (odds ratio 2.18 ; $95 \%$ confidence interval 1.18 to $4.01 ; p=0.01$ ).

\section{Discussion}

We have found a significant association between ACE gene polymorphism and SACE activity in both patients with sarcoidosis and control subjects. This association, and the distribution of the three ACE genotypes in our Japanese population, has led to three important findings. Firstly, allele I was the more frequent and a relative excess of genotype II (46\%) was recognised in controls compared with white skinned subjects. ${ }^{913}$ In other words, it is probable that Japanese subjects in general may have genetically lower SACE levels. Secondly, although the exact mechanism by which SACE levels are increased in patients with sarcoidosis has not been elucidated, induction of SACE in patients seems to be considerably regulated by this polymorphism, and the presence or absence of allele $\mathrm{D}$ is associated with higher or lower SACE levels in patients with sarcoidosis. Thirdly, the wholereferenceinter- val for SACE levels depends on the distribution of the three ACE genotypes in a given normal population, and we have discriminated abnormal SACE levels more precisely by establishment of the three reference intervals for each genotype. If we use the whole reference interval, we underestimate SACE levels in patients with genotype II and overestimate those with genotype DD. SACE levels in patients with genotype II almost corresponded to those in controls with genotype DD (fig 1). In particular, the new reference interval improved diagnostic sensitivity from $6 \%$ to $60 \%$ in patients with genotype II. The variation in distribution of the ACE genotype among races can partly explain the considerable difference found in the incidence of increased SACE levels in patients with sarcoidosis in previous reports. ${ }^{2}$

Subgroup analyses of both allele frequencies revealed an excess of allele $\mathrm{D}$ in female patients. The presence of allele D - namely, genotype DD plus ID - was associated with a significant increase in the risk for sarcoidosis in women (odds ratio 2.18), whereas no significant association was seen in men. In this regard, Lieberman reported that black patients tend to have higher SACE levels than whites, ${ }^{3}$ and a definitely increased risk in black American women has also been reported. ${ }^{14}$ In fact, allele $\mathrm{D}$ has been more frequently recognised in black subjects than in whites. ${ }^{15}$ On the other hand, the increased frequency of allele I $(0.70)$ has been reported in Chinese, ${ }^{16}$ and sarcoidosis is rarely seen in China. ${ }^{17}$ These epidemiological findings are consistent with our current finding that genotype DD or ID, which is associated with higher SACE levels, may contribute genetic predisposition to sarcoidosis, at least in women. As this is a limited subgroup population study, we have initiated an international collaborative study on ACE gene polymorphism in sarcoidosis to verify our findings. 
This study was not aimed at identification of the mechanism by which ACE gene polymorphism may affect sarcoidosis. Our association study does not exclude the possibility that ACE gene polymorphism is in linkage disequilibrium with other unknown genetic variants concerned with susceptibility to sarcoidosis. It is, however, attractive to hypothesise that ACE directly participates in the immune response in sarcoidosis because of the following observations. Monocyte-macrophage-epithelioid cell lineage contributes significantly to the increase in SACE levels in patients with sarcoidosis. ${ }^{18} 19$ It has recently been shown that ACE is expressed in $\mathrm{T}$ lymphocytes and that the level of expression in those cells is associated with ACE gene polymorphism. ${ }^{20}$ ACE or its related substrates or products are also known to have various functions in the immune system, ${ }^{21-25}$ so it is reasonable to continue to study this genetic marker in the ACE gene with a view to elucidating the nature of the association.

In conclusion, concomitant determination of the ACE genotypes and SACE levels helps us to discriminate abnormal SACE levels more accurately. Although the data do not allow us to conclude definitely that the $\mathrm{D}$ allele in the ACE gene mediates an increased risk for sarcoidosis, further investigations of new roles of ACE in the pathogenesis of sarcoidosis and the exact mechanism of ACE gene expression will elucidate a new aspect of the significance of genetic factors for sarcoidosis.

The authors are indebted to Dr Akira Aida for his statistical suggestions and to Ms Sachie Yuhki for her excellent technical assistance.

1 Lieberman J. Elevation of serum angiotensin-convertingenzyme (ACE) level in sarcoidosis. Am $\mathcal{F}$ Med 1975 59:365-72.

2 Fraser RG, Paré JAP, Paré PD, Fraser RS, Genereux GP. Pulmonary disease of unknown origin. In: Bralow L, ed Diagnosis of diseases of the chest. 3rd ed. Philadelphia: WB Saunders, 1991:2604-711.

3 Lieberman J, Nosal A, Schlessner L A, Sastre-Foken A. Serum angiotensin-converting enzyme for diagnosis and therapeutic evaluation of sarcoidosis. Am Rev Respir Dis therapeutic evaluation

4 Neels HM, Scharpe SL, Van Sande ME, Vervek RM, Van Acker KJ. Improved micromethod for assay of serum angiotensin converting enzyme. Clin Chem 1982;28:1352-5.

5 Silberstein LE, Berkman LE, Fanburg BL. Angiotensin-Iconverting enzyme (ACE) activity in serum following plasma exchange. Proc Soc Exp Biol Med 1983;173:222-6

6 Fogarty Y, Fraser CG, Browning MCK. Intra- and inter-individual variation of serum angiotensin converting
enzyme. Clinical implications. Ann Clin Biochem 1989; 26:201-2.
7 Cambien F, Alhenc-Gelas F, Herbeth B, Andre JL, Rakotovao R, Gonzales MF, et al. Familial resemblance of plasma angiotensin-converting enzyme level. The Nancy study. Am $\mathcal{F}$ Hum Genet 1988;43:774-80.

8 Soubrier F, Alhenc-Gelas F, Hubert C, Allegrini J, John M, Tregear G, et al. Two putative active centers in human angiotensin I-converting enzyme revealed by molecular cloning. Proc Natl Acad Sci US A 1988;85:9386-90.

9 Rigat B, Hubert C, Alhenc-Gelas F, Cambien F, Corvol P, Soubrier F. An insertion/deletion polymorphism in the angiotensin I-converting enzyme gene accounting for half the variance of serum enzyme levels. F Clin Invest 1990;86:1343-6.

10 Kasahara Y, Ashihira Y. Colorimetry of angiotensin-I converting enzyme activity in serum. Clin Chem 1981; 27:1922-5.

11 Rigat B, Hubert C, Corvol P, Soubrier F. PCR detection of the insertion/deletion polymorphism of the human angiotensin converting enzyme gene (DCP1) (dipeptidyl carboxypeptidase 1). Nucleic Acids Res 1992;20:1433.

12 Furuya K, Yamaguchi E, Hirabayashi T, Itoh A, Hizawa N, Ohnuma $\mathrm{N}$, et al. Angiotensin-I-converting enzyme gene polymorphism and susceptibility to cough. Lancet 1994; polymorp

13 Cambien F, Poirier O, Lecerf L, Evans A, Cambou JP, Arveiler D, et al. Deletion polymorphism in the the gene for angiotensin-converting enzyme is a potent risk factor for myocardial infarction. Nature 1992;359:641-4.

14 Mayock RL, Bertrand P, Morrison CE, Scott JH. Manifestations of sarcoidosis. Analysis of 145 patients, with a review of nine series selected from the literature. Am $\mathcal{f}$ Med 1963;35:67-89.

15 Bloem LJ, Manatunga AK, Boatright E, Pratt JH. Relation of race and a polymorphism in the angiotensin I-converting enzyme gene to enzyme levels (abstract). Hypertension 1993;22:407.

16 Lee EJ. Population genetics of the angiotensin-converting enzyme in Chinese. Br f Clin Pharmacol 1994;37:212-4.

$17 \mathrm{Da}$ Costa JL. Geographic epidemiology of sarcoidosis in southeast Asia. Am Rev Respir Dis 1973;108:1269-72.

18 Pertschuk LP, Silverstein E, Friedland J. Immunohistologic diagnosis of sarcoidosis: detection of angiotensinconverting enzyme in sarcoid granulomas. Am $\mathcal{f}$ Clin Pathol 1981;75:350-4.

19 Okabe T, Yamagata K, Fujisawa M, Watanabe J, Takaku F. Increased angiotensin-converting enzyme in peripheral blood monocytes from patients with sarcoidosis. $\mathcal{F}$ Clin Invest 1985;75:911-4.

20 Costerousse O, Allegrini J, Lopez M, Alhenc-Gelas F. Angiotensin I-converting enzyme in human circulating mononuclear cells: genetic polymorphism of expression in nuclear cells: genetic polymorphism of

21 Weinstock JV, Kassab J. Chemotactic response of splenic mononuclear cells to angiotensin II in murine schistosomiasis. F Immunol 1986;137:2020-4.

22 Weinstock JV, Blum AM, Kassab J T. Angiotensin II is chemotactic for a T-cell subset which can express somiasis mansoni. Cell Immunol 1987;107:180-7.

23 Kozlowski S, Corr M, Takeshita T, Boyd LF, Pendleton CD, Germain RN, et al. Serum angiotensin-1 converting enzyme activity processes a human immunodeficiency virus $1 \mathrm{gp} 160$ peptide for presentation by major histocompatibility complex class I molecules. F Exp Med 1992; 175:1417-22.

24 Kozlowski S, Corr M, Shirai M, Boyd LF, Pendleton CD, Berzofsky JA, et al. Multiple pathways are involved in the Berzofsky JA, et al. Multiple pathways are involved in the tides. F Immunol 1993;151:4033-44.

25 Sherman LA, Burke TA, Biggs J. A. Extracellular processing of peptide antigens that bind class I major histocompatibility molecules. $\mathcal{F}$ Exp Med 1992;175:1221-6. 